\title{
Work Design: Rethinking How Technology Is Used In University Classrooms
}

\author{
Leslie J. Wardley ${ }^{1}$, Charles H. Bélanger ${ }^{2} \&$ Suchita Bali $^{3}$ \\ ${ }^{1}$ Organizational Management, Shannon School of Business, Cape Breton University, Nova Scotia, Canada \\ ${ }^{2}$ Management, Faculty of Management, Laurentian University, Ontario, Canada \\ ${ }^{3}$ Faculty of Human Studies, Laurentian University, Ontario, Canada \\ Correspondence: Leslie J. Wardley, Organizational Management, Shannon School of Business, Cape Breton \\ University, Nova Scotia, Canada. E-mail: leslie.ljw@gmail.com
}

Received: April 6, 2018

doi:10.5539/ijbm.v13n9p1
Accepted: July 19, 2018

URL: https://doi.org/10.5539/ijbm.v13n9p1

Online Published: August 2, 2018

\begin{abstract}
Driven by perceived millennial student expectations, the in-class use of mobile technology is becoming increasingly popular in postsecondary institutions. Thus, it is important to gain insights into students' self-competence and learning transferability when using these technologies within the learning environment. This study was undertaken to assess an iPad iLearn Program in a school of business after students had been provided with an on-loan tablet that would become their property after a pre-determined period of enrollment. In this study, comfort with technology, comfort with iPad, perceptions of iPad, and frequency of use were all significant predictors of learning transferability. The adjusted $\mathrm{R}^{2}$ explained $72 \%$ of the variance in the model. Moreover, this study found there were significant differences for these predictor variables depending on university support of the program and tablet ownership. This reinforces the point that when selectively targeting this generation by promoting in-class use of tablet technology, institutions must provide the needed resources.
\end{abstract}

Keyword: millennials, tablet technology, mobile technology, digital technology, learning transferability, iLearn, iPad

\section{Introduction}

Over the past several years, there has been a significant advancement in the choices of digital technologies available in the field of teaching and learning (Maddux \& Johnson, 2012). Many traditional classrooms are now attempting to transform into more of a two-way communication laboratory that prompts educators to fulfill the role of knowledge facilitators (Kukulska-Hulme, 2013) where students are active participants. Technology has advanced this collaborative approach through students' use of the Internet on mobile devices for everyday tasks, both inside and out of the classroom, and through changes made to course delivery options. There are a number of factors that could account for these shifts in teaching methods, including demands of our 21st-century workforce, attempts to improve student engagement and retention (Dobbins \& Denton, 2017), and the much-debated characteristics of the 'always connected' generation of students who, assumedly, have shifted their patterns of learning and technology use from previous generations (Bullen, Morgan \& Qayyum, 2011; Jones \& Czerniewicz, 2010).

Firstly, current job market demands expect fresh graduates to have developed adequate social skills in order to work collaboratively in teams at their future workplaces (Alvarez, Alarcon \& Nussbaum, 2011). This particular trend has prompted educators to somewhat modify students' job design and to encourage them to get more engaged in classrooms (Barnes, 2014; Saorin, Torre, Martin \& Carbonell, 2013). Students' job design can be defined in educational situations as the conceptual or practical examination of factors that influence work and learning into a motivational structure that increases performance or achieves desired outcomes (Cohen, 2012; Hackman \& Oldham, 1976, 1980; Morgeson \& Humphrey, 2006). The use of technology has also allowed higher education providers to offer flexible course delivery options, which are an important consideration when students are selecting academic institutions (Baasanjav, 2013). Morris, Ramsay \& Chauhan (2012) found that 50\% of students surveyed indicated that the offer of a mobile device would have influenced their university application decisions. 
Secondly, students who belong to the millennial generation (those born between the early 1980s to early 2000s) have been raised with digital technology. The growth of online and blended delivery courses is underscoring the demand for more flexible education programs where students are presented with the opportunity of taking more control of their work and work environment. Although they have come to expect technology to be meshed into their education (Kinash, Brand, \& Mathew, 2012; Tanaka, Hawrylyshyn \& Macario, 2012), studies indicate they also expect to be taught in traditional ways (Henderson, Selwyn, Finger \& Aston, 2015; Margaryan, Littlejohn \& Vojt, 2011). It is important for higher education institutions to pay attention to technology-driven learning practices but it is equally essential that they do not give total credence to undocumented claims of current generations having developed radically new cognitive patterns and learning styles (Barnes, 2014; Margaryan, Littlejohn, \& Vojt, 2011; Vu, McIntyre, \& Cepero, 2014; Author \& Mang, 2015.

Finally, many postsecondary establishments employ technology to improve student-learning experiences in the hopes of staying competitive and attaining higher student retention (Diemer, Fernandez \& Streepey, 2012). All of the reasons mentioned above, are adding a new layer to the complexities of the education "business". Universities and colleges are targeting technology as a means to remain competitive with student recruitment as well as to enhance students' personal and academic experience. Despite the obvious ubiquity of technology in everyday life, adoption of mobile learning in classrooms still seems to be prominently fragmented (Kukulska-Hulme, 2013).

\section{Purpose of the Research}

Therefore, the purpose of this study was to determine which factors influenced students' self-competence when using iPad technology after an institution had enrolled its business students in an iPad iLearn experimental program.

The study design was set up to statistically test three main hypotheses:

$\mathrm{H}_{1}$ : Learning transferability can be predicted by variables such as comfort with iPads and ease with technology in general as well as iPad perceptions and frequency of use.

$\mathrm{H}_{2}$ : There will be a significant difference between students who feel university support is adequate and those who do not on the five variables identified: comfort with iPads, ease with technology, iPad perceptions, frequency of use, and learning transferability.

$\mathrm{H}_{3}$ : There will be a significant difference on the five variables used in $\mathrm{H}_{2}$ between students who own an iPad and those who borrow one upon need.

\section{Review of Literature}

\subsection{Popularity of Mobile Devices in Classrooms}

Wireless technology, including laptops, tablet computers, and mobile phones is becoming increasingly popular. A number of studies indicate that the use of mobile devices in a classroom environment promotes students' motivation (emotional), participation (behavioral) and assists in collaborative learning (cognitive) (Barak, Lipson \& Lerman, 2006; Dobbins \& Denton, 2017; Kukulska-Hulme, 2013). Even though somewhat older technologies, in particular laptop computers have established their predominance in classrooms, mobile tools such as iPads and other tablet computers do offer other advantages such as better mobility, lightweight, convenience to carry, handwriting recognition, responsive touchscreen and ease of use, but are not found to be core academic tools for the majority of students (Crichton, Pegler \& White, 2012; Dearnley, Haigh, \& Fairhall, 2008; Hashim, 2014; Henderson, Selwyn, Finger \& Aston, 2015; Morris et al., 2012; Murphy \& Williams, 2011; Saorin et al., 2013; Sullivan, 2013; Tanaka et al., 2012; Author \& Mang, 2015; Welsh et al., 2015). When available, tablet computers allow students to perform several hands-on tasks, such as note-taking, highlighting and annotating, e-book capabilities, presentation-support application, participatory simulations, and collaborating with their peers and instructors, which otherwise would be less easily achievable with a laptop computer (Alvarez et al., 2011; Diemer et al., 2012; Mang \& Author, 2012, 2013; Sloan, 2013; Welsh et. al, 2015; Wu, Kuo \& Wu, 2013).

However, there are many associated challenges that cannot be overlooked, including those hereafter presented. Research indicates that technological initiatives could negatively affect students' experience by causing negative emotions, such as anxiety (Dearnley et al., 2008). Additionally, tablet computers could end up becoming a distraction rather than assistance in a classroom setup, hence, negatively impacting the overall academic performance (Barak et al., 2006; Gaudreau, Miranda \& Gareau, 2014; Sloan, 2013). Furthermore, the risk of overuse leading to technology addiction has also been documented (Hargittai, 2010). Last but not least, when working with handheld devices, it is almost impossible to determine if students are using it for gaming, social media networking, blogs, or other unauthorized usage during class and exam sessions (Magazine, 2012). 


\subsection{Implementation Strategy of Tablets in Classrooms}

Establishing the use of tablets in lecture rooms should be considered more as a change process than a sudden break from past practices (Barnes, 2014). Fullan (2001) hypothesized that innovation projects go through three phases: a) initiation, that is, the decision to adopt an innovation; b) implementation, which consists of putting the innovation into practice; and c) institutionalization, when the innovation becomes part of the regular practice. Critical implementation factors heavily depend on how well it is adopted and accepted by the faculty, as well as the students (Alvarez et al., 2011; Dearnley et al., 2008; Wong, 2012). Wong (2012) contends that a successful implementation of technology-based learning initiatives requires a few basic conditions, such as faculty buy-in, a durable infrastructure that supports a strong wireless network and bandwidth, and investment with continuing support.

On the other hand, Dearnley et al. (2008) stress that training for both students and faculty is central to accomplishing educational goals when introducing technology. The authors argue that a lack of training puts additional workload, especially on the students, as they try to tune their mindset and adapt to the new classroom environment. Additionally, Alvarez et al. (2011) suggest that it is imperative to define clear roles for teachers, students and technologists. As the lead stakeholder, faculty must provide a consistent lesson plan designed around problem-solving methodologies, formative assessment tools and participatory simulations. As institutions mull over the introduction of tablets in the classroom, not only must they consider financial and staff implications, but also the impact it will have on students' application decisions (Morris et al., 2012)

\subsection{Learner's Acceptance of Technology and Purpose of Use}

A sound implementation strategy is only one part of the picture; success of any technology-enhanced initiative also depends upon the learners' level of acceptance, perceived usefulness and adoption of the technology. Studies highlight connections between students achieving their academic goals and demonstrating high confidence in using technology (Wu et al., 2013) as well as between performing course-related work, sometimes referred to as 'self-efficacy' (Bandura, 1997) and learning and engagement (Diemer et al., 2012). A Canadian study revealed that students, as well as faculty, do possess a sound sense of self-competence, and are well-equipped and highly motivated towards engaging in learning environments driven by technology (Kenny, Van Neste-Kenny, Burton, Park, \& Qayyum, 2011). Further, Morris et al. (2012) found that students who felt they had a strong grasp of ordinary technology use were able to approach the introduction of a new device with a positive attitude, which is important for e-learner satisfaction.

An interesting distinction was made by Henderson et al. (2015) who classified the use of digital technologies in two categories, student logistics and student learning. The logistical aspects relate to the more pragmatic tasks a university student has to perform on a daily basis, such as doing and submitting assignments, scheduling activities, retrieving documents, and a slew of other actions to remain socially and academically informed. These authors and others (Bennett and Maton, 2010; Dobbins \& Denton, 2017; Margaryan et al., 2011) found that the dominant digital technology models of student learning were still more in tune with the typically conservative and passive consumption and transmission of knowledge than the mythically spectacular advancements postsecondary education institutions are loosely suggesting.

\subsection{Learning Transferability and Frequency of Use}

Kinash et al. (2012) and Rossing, Miller, Cecil, and Stamper (2012) presented results concerning students' perceptions of tablets based on the use of Apple iPads during one or more class sessions of a course. Students generally held positive views regarding improved motivation in both studies. However, there were differences in perceptions of "technological learning transferability" which has been inferred to mean learners' ability to apply technological skills developed through the everyday use of devices to the learning environment (Gaudreau et al., 2013; Kinash et al., 2012; Morris et al., 2012; Welsh et al., 2015). In the Rossing et al. (2012) study, students expressed a belief the device increased learning while Kinash et al. (2012) found that students were not convinced the devices significantly improved their learning. The more recent study by Welsh et al. (2015) found seventy-two percent of students reported that their perceptions of tablet use to support learning had improved over the course of using tablets in field study courses. This difference could be attributed to the frequency of use and changes in tablet technology over the time of the studies being conducted. This is further supported by Morris et al.'s (2012) findings that with frequency of use the perceptions of students became more positive about the device and available Apps. Both Kinash et al. (2012) and Rossing et al. (2012) provide only post-experience perceptions of the technology and do not approach the subject of how student perceptions of the device might change after repeated use.

Although beyond the scope of this study, it is important to understand that the background of this study provides 
plenty of research which has debunked the myth of the 'millennials', the 'digital natives', and the NetGen as a generation who has adopted totally different patterns of learning and technology use in the classroom. In fact, they appear to conform to traditional pedagogies as this brief literature review has hinted.

\section{Research Methodology and Approach}

\section{1 iLearn iPad Program}

Starting in 2012, a new iLearn Program was introduced at a School of Business (SB) undergraduate program in hopes of enhancing the learning environment and increasing enrollment. As part of this iLearn program, every first-year student enrolled in the business program received an iPad in their first week of school. This iPad was on loan but ownership would revert to the student when they graduated pending enrollment in a BBA or BComm program for a predetermined length of time. In support of this program, professors were to encourage the use of the tablet technology in-class. For students who fell outside of the program criterion (e.g., those taking a business elective or enrolled before 2012), iPads could be borrowed from a mobile tablet cart for in-class work.

\subsection{Sample and Statistical Tests}

Data collection for this research project occurred in the third year of the iLearn iPad Program during the 2015 winter term within an eight-week timeframe. A link to an online survey was provided to undergraduate students in business courses so they could access the survey using their tablets and other mobile devices or personal computers. Professors teaching on-campus business classes that had been categorized as part of the iLearn program were contacted via email requesting that a Research Assistant (RA) come into their classes to explain the purpose of the research and to provide a link to the survey. All of the professors contacted allowed the RA entrance to their classes. In total, there were 153 student responses to the request for further feedback on their experiences and perceptions about the use of the tablets as part of their business studies.

When using an online survey link that does not track participants' identifying information, it is not possible to determine a precise response rate. It becomes even more difficult when in-person requests to complete the survey are made to students who may be taking multiple business classes. To avoid duplicating students in the classroom count, the RA distributed the information containing the survey link to those who had not completed the survey using leaflets and asked students to complete the survey only once. Based on a count of leaflets distributed, the RA contacted 160 unique students through in-class solicitation with most professors allowing students to complete the survey during class time. Thus, the response rate would be $96 \%$ of those directly contacted or $45 \%$ of the total SB student population of 339. The participant size was further reduced to 136 useable responses after sorting and cleaning the data files by removing any surveys that were substantially incomplete or did not contain key demographic information.

Even though the sample mainly consisted of those in the SB who would had been given a tablet as part of their enrolment, there were also students who were borrowing the tablets from a loaner cart provided as part of the iPad iLearn Program. Students were asked to provide information regarding gender, age and area of study, but no attempt was made to connect the information collected to individual students so the responses remained anonymous. The responses were collected over a short-time period (eight weeks); we were able to discuss differences in the overall viewpoints expressed. Proper ethics approval to conduct the survey was obtained from the institution.

\subsection{Approach to Analysis}

An analysis of the data consisted of a three-step process using separate statistical procedures. First, the constructs were assessed using exploratory and confirmatory factor analysis. Second, linear regression was used to test the independent constructs to ascertain whether they influenced the dependent variable, namely, learning transferability. Third, to determine if significant differences existed, a test of significance between population means was conducted using independent t-tests based on the presence of university support and owning an iPad.

\section{Results and Discussion}

\subsection{Profile of Research Respondents}

There were some minor differences in the blend of academic concentrations within the survey population $(\mathrm{N}=$ 136) with 26 students or $19 \%$ of the sample coming from a range of majors other than business. Other demographic markers are worth pointing out. The overwhelming majority (93\%) of students were under 26 years of age and so would have been born between 1989 and 1998, fitting within the millennial generation exposed to the use of digital technology throughout their lifespan (Tanaka et al., 2012). This point becomes important when exploring comfort with the use of technology and perceptions of its worth after graduation. The span of years 
spent in school offered some diversity as $29 \%$ were in their $1^{\text {st }}$ year of study, $39 \%$ were in their $2^{\text {nd }}$ or $3^{\text {rd }}$ year of study, 29\% had been studying for 4 to 5 years and 3\% had been studying for 6 or more years.

The respondents' gender breakdown revealed a slightly higher proportion of female respondents $(59 \%)$ to male respondents (41\%). During statistical analysis, gender was ruled out as a significant factor so no attempt was made to make generalizations based on this descriptor. The percentage of students who owned their iPad (71\%) was higher than those who were using the borrowed in-class iPad cart (29\%). Other pertinent information regarding the frequency of tablet use and where students learned about the tablet program are included in Table 1. It is important to note that most of the survey participants had not learned about the tablet program before enrolment (54\%); those who were familiar with the program obtained their information mainly from recruiters $(19 \%)$ and the university website (11\%).

Table 1. Demographic characteristics and other information

\begin{tabular}{llll}
\hline & & Frequency & Percent \% \\
\hline Gender & Male & 56 & 41 \\
Total & Female & 80 & 59 \\
Age & & 136 & 100.0 \\
& 17 to 20 & 60 & 44 \\
Total & 21 to 25 & 67 & 49 \\
Years in Study & 26 or older & 9 & 7 \\
& & 136 & 100.0 \\
& 1 to 2 & 39 & 29 \\
& 2 to 3 & 53 & 39 \\
Total & 4 to 5 & 39 & 29 \\
Heard & 6 or more & 5 & 3 \\
program from & & 136 & 100.0 \\
& theUniversity Website & 15 & 11 \\
& Recruiter & 26 & 19 \\
& Campus Visit & 12 & 9 \\
Total & University Fair & 5 & 4 \\
Heard Before Attending Yes & No & 136 & 57 \\
& & 61 & 100.0 \\
Total & No & 73 & 45 \\
\hline
\end{tabular}

* Either did not hear about program before attending or heard from a source not listed.

\subsection{Assessment of the Model Constructs}

As indicated under 4.3 above, the first order of business in this study was to aggregate the variables (in this case, the questions) that seemed to be the most interdependent using exploratory and confirmatory factor analysis. This multivariate statistical method reduced the variables into a few parsimonious unidimensional factors that had the highest Cronbach's alpha coefficients. Five constructs with internal consistency ranging from 0.853 to 0.912 were identified and retained as the model variables. Table 2 presents them in greater detail. 
Table 2. Factor analysis and Cronbach's alpha

\begin{tabular}{|c|c|c|c|c|}
\hline Construct & Scale Items & $\begin{array}{l}\text { Range of } \\
\text { Loading }\end{array}$ & $\begin{array}{l}\text { Cronbach if } \\
\text { removed }\end{array}$ & $\begin{array}{l}\text { Cronbach's } \\
\text { Alpha }\end{array}$ \\
\hline \multirow[t]{5}{*}{$\begin{array}{l}\text { Comfort with } \\
\text { Technology }\end{array}$} & $\begin{array}{l}\text { I feel confident troubleshooting my own computer technology } \\
\text { problems }\end{array}$ & .842 & .870 & .883 \\
\hline & I feel confident learning advanced skills with computer technology & .818 & .849 & \\
\hline & I feel confident getting computer software up and running & .782 & .852 & \\
\hline & I feel confident learning to use a variety of programs (software) & .756 & .856 & \\
\hline & $\begin{array}{l}\text { I feel confident showing other students how to use a wide range of } \\
\text { devices i.e. computer, cellphone, other }\end{array}$ & .750 & .862 & \\
\hline \multirow[t]{7}{*}{$\begin{array}{l}\text { Comfort } \\
\text { iPad }\end{array}$} & I feel confident getting applications on the iPad up and running & .852 & .976 & .900 \\
\hline & I feel confident using the Internet on the iPad & .825 & .896 & \\
\hline & I feel confident working on an iPad & .727 & .881 & \\
\hline & I feel confident demonstrating my knowledge of the iPad & .693 & .875 & \\
\hline & $\begin{array}{l}\text { I feel that I have the technological skill to use the iPad to enhance my } \\
\text { learning }\end{array}$ & .589 & .883 & \\
\hline & I feel too intimidated to use the iPad & .536 & .901 & \\
\hline & I feel confident learning advanced skills with the iPad & .522 & .879 & \\
\hline \multirow[t]{5}{*}{$\begin{array}{l}\text { Perceptions } \\
\text { the iPad }\end{array}$} & $\begin{array}{l}\text { I feel that regular use of the iPad for my studies will be useful for the } \\
\text { workplace }\end{array}$ & .817 & .881 & .905 \\
\hline & $\begin{array}{l}\text { I feel that students using the iPad in their studies will be better } \\
\text { prepared than other non-user students }\end{array}$ & .801 & .890 & \\
\hline & $\begin{array}{l}\text { I feel that the iPad will be a good learning tool for self-directed } \\
\text { learning }\end{array}$ & .800 & .883 & \\
\hline & I feel that using the iPad is a waste of time recoded & .783 & .882 & \\
\hline & I feel the iPad will enhance the student experiences in my courses & .723 & .883 & \\
\hline \multirow[t]{4}{*}{ Frequency of use } & How often do you use an iPad outside of class for course related work? & .805 & .822 & .853 \\
\hline & $\begin{array}{l}\text { How often do you use an iPad for course related purposes in your } \\
\text { classes? }\end{array}$ & .777 & .805 & \\
\hline & $\begin{array}{l}\text { How often do you use an iPad outside of class for functions not related } \\
\text { to your courses? }\end{array}$ & .770 & .792 & \\
\hline & $\begin{array}{l}\text { How often do you use an iPad for purposes not related to course } \\
\text { content in your classes? }\end{array}$ & .767 & .834 & \\
\hline \multirow[t]{6}{*}{$\begin{array}{l}\text { Learning } \\
\text { transferability }\end{array}$} & $\begin{array}{l}\text { I feel confident about using the iPad for aspects of my course } \\
\text { assessment i.e. tests }\end{array}$ & .596 & .894 & .912 \\
\hline & $\begin{array}{l}\text { I feel confident troubleshooting other students' problems with their } \\
\text { iPad }\end{array}$ & .595 & .888 & \\
\hline & I feel confident about presenting my work in class using an iPad & .591 & .897 & \\
\hline & I feel confident troubleshooting my own iPad problems & .540 & .906 & \\
\hline & I feel confident using the iPad to assist in my daily routines & .532 & .897 & \\
\hline & $\begin{array}{l}\text { I feel confident using the iPad for my course homework and } \\
\text { assignments }\end{array}$ & .487 & .891 & \\
\hline
\end{tabular}

\subsection{Results of Linear Regression on Learning Transferability}

The results indicate the four-predictor model on learning transferability was a good fit (Table 3), with the equation explaining a statistically significant portion of the variability in the dependent variable $(\mathrm{F}=87.808 ; \mathrm{p}$ $<.05)$. The adjusted R Square statistic $\left(\mathrm{R}^{2}\right)$ demonstrates that the model explains $72 \%$ of the variance in the model with all four of the predictors constructs achieved p-values less than .05 indicating significance. There were positive standardized $\beta$ eta coefficients for all of the constructs, and when ranked according to $\beta$ eta size, we can conclude that a change in comfort with iPad $(\beta=.472 ; \mathrm{p}<.05)$ and perceptions of iPad $(\beta=.294 ; \mathrm{p}<.05)$ have greater relative effects on learning transferability than a change in comfort with technology $(\beta=.182 ; \mathrm{p}$ $<.05)$ or frequency of iPad use $(\beta=.168 ; \mathrm{p}<.05)$. 
Table 3. Linear regression of external factors on learning transferability

\begin{tabular}{|c|c|c|c|c|c|c|}
\hline Adj. R-Square & Std. Error & & $\mathrm{F}$ & Sig. of $F$ & & \\
\hline $\mathrm{R}^{2}=.720$ & .512 & & 87.808 & .000 & & \\
\hline Relationship & $\begin{array}{l}\text { Std. } \\
\text { Coeff. }\end{array}$ & Beta & Std. Error & $\mathrm{t}$ & Sig. of $t$ & Collinearity (VIF) \\
\hline Comfort with iPad & .472 & & .077 & 7.96 & .000 & 1.699 \\
\hline Perceptions of iPad & .294 & & .066 & 5.22 & .000 & 1.531 \\
\hline Comfort with technology & .182 & & .066 & 3.42 & .001 & 1.370 \\
\hline Frequency of use iPad & .168 & & .058 & 3.27 & .002 & 1.313 \\
\hline
\end{tabular}

\subsection{Predicting Learning Transferability}

The research study's findings point to how students' comfort with tablets (in this case iPads) and their perceptions of how they fit with their future goals are worth considering when deciding to implement this type of technology in university classrooms (Table 3). The independent variables comfort with iPad and perceptions of $i$ Pad had the largest $\beta$ eta sizes respectively $(\beta=.472 ; \mathrm{p}<.05)$ and $(\beta=.294 ; \mathrm{p}<.05)$ so they were the most predictive of learning transferability. This finding is not surprising and confirms prior research (Diemer et al., 2012; Morris et al., 2012; Wu et al., 2013). When one feels more comfortable with a form of technology it becomes easier to integrate its use in classroom activities. In addition, if students perceive the long-term benefits of using the tablet, as it can offer differentiation of job skills, this perception would act as a motivator when attempting to overcome any proficiency deficiencies.

Comfort with technology $(\beta=.182 ; \mathrm{p}<.05)$ was also predictive of learning transferability. Computing technology has gone mainstream within our society mainly driven by perceptions about its use in business and social networking pressures (Wallace \& Clariana, 2005). This study supports Morris et al.'s (2012) findings as it appears that one's ability in being able to switch between different software applications and developing troubleshooting skills are important and have carryover to other forms of technology (e.g., cellphones). Thus, students are likely to have had significant experience with computer technology prior to entering postsecondary education. Self-efficacy in the use of other forms of technology appears to carry over to the use of tablets.

Frequency of iPad use $(\beta=.168 ; \mathrm{p}<.05)$ had the lowest predictive ability to determine learning transferability. What is interesting about this finding is that this construct was developed to consider the frequency of use and not how the tablet was being used. Thus, off-topic and on-topic use in class and use outside of class were combined. Frequent manipulation of the applications during classroom time could be perceived as "counter-productive" by professors (Barak et al., 2006; Gaudreau, 2014; Tanaka et al., 2012) but if students are using the tablet more they are becoming more proficient with the tablet which increases students' self-efficacy (Diemer et al., 2012; Welsh et al., 2015; Wu et al., 2013). Based on this logic, all aspects of use were included into a single construct and not divided into perceived 'positive' and 'negative' in-class behaviour. The dependent variable of learning transferability was constructed to measure learning transferability of the technology in general (i.e. helping others, daily routine) and not how it impacted in-class productivity so measuring frequency of use was the most important aspect to capture. Overall, hypothesis $\mathrm{H}_{1}$ was fully supported in that the four variables proved to be significant predictor of the learning transferability dependent variable.

\subsection{Differentiating Based on University Support}

The t-test results are presented below for university support on the basis of their mean differences. Table 4 reveals that comfort with iPad, perceptions of the iPad, comfort with technology and learning transferability were found to have significantly different means based on university support with $\mathrm{p}$-values $<.05$. Thus, those who did not feel they had adequate university support reported less comfort with the tablet and less comfort with technology in general and also more negative views of the tablet and their ability to use the devices effectively i.e., learning transferability. Keeping the direction of these scales in mind (i.e., $5=$ strongly disagree and $1=$ strongly agree), for each of the factors with significant differences, the students who did not feel adequately supported by the university reported a higher mean compared to those who did feel supported.

The one variable where no significant mean difference $(p=>.05)$ was found based on university support is the frequency of iPad use. What our paper's findings are really pointing out is that there is no difference in frequency of tablet use for university study between those who feel and those who do not feel properly supported by the university. Students have similar patterns of tablet use; however, those students without support they did not become more comfortable with the tablet or other technologies, held a more negative view of the iPad and 
expressed lower levels of learning transferability. These findings appear to be similar to Welsh et al., (2015) as their study had connected frequency of use to better learning transferability and higher levels of technology self-efficacy. Therefore, hypothesis $\mathrm{H}_{2}$ is generally supported with the exception of the variable frequency of use, which was not influenced by university support.

Table 4. Mean scores comparison for university support

\begin{tabular}{lllll}
\hline \multirow{2}{*}{ Construct } & \multicolumn{2}{c}{ Mean Scores: University Support } & & \multirow{2}{*}{ Sig. } \\
\cline { 2 - 5 } & $87 \%$ Yes $(\mathrm{n}=119)$ & $13 \%$ No $(\mathrm{n}=17)$ & 1.12 & .002 \\
\hline Comfort with tablet & 1.81 & 2.40 & 2.49 & .011 \\
Perceptions of tablet & 2.52 & 3.14 & 2.49 & .002 \\
Comfort with technology & 1.86 & 2.49 & .09 & .114 \\
Frequency of tablet use & 3.64 & 4.10 & .915 & .006 \\
Learning transferability & 2.51 & 3.19 & & \\
\hline
\end{tabular}

\subsection{Differentiating Based on iPad Ownership}

The t-test results are presented below for iPad ownership on the basis of their mean differences. Comfort with iPad, comfort with technology and frequency of iPad use were all found to have significantly different means based on iPad ownership with p-values $<.05$. Thus, as expected, those who were part of the iPad iLearn Program and had been given an iPad or already owned one were more comfortable with the device, had increased comfort with technology and used the iPad more frequently.

What is surprising, based on Table 5 findings, is that ownership did not appear to impact students' perceptions of the iPad or learning transferability. Both of these constructs were not found to have significantly different means based on ownership of the tablet with p-values $>.05$. One would have to assume that the increased opportunity of out-of-class use for those who owned the device would have resulted in differences in these areas. It is intimating that ownership of the devices does not appear to impact the value and importance students place on the use of the device in their education or their future employment goals. These findings are similar to those of Morris et al., (2011) who found that undergraduate students could make use of tablets to enhance their learning without institutions changing their teaching methods or its computer systems. As digital natives, millennials have technological skills and experiences that allow them to make good use of technology in their learning without institutions selecting the time and circumstances for them. Fittingly, results of hypothesis $\mathrm{H}_{3}$ were mixed. Learning transferability and perceptions of iPad were not influenced by tablet ownership while ownership made students more nimble with the device and used it more frequently.

Table 5. Mean scores comparison for Ipad ownership

\begin{tabular}{lllc}
\hline \multirow{2}{*}{ Construct } & Mean Scores: Own an iPad & & F \\
& $71 \%$ Yes $(\mathrm{n}=97)$ & $29 \%$ No $(\mathrm{n}=39)$ & .001 \\
\hline Comfort with tablet & 1.71 & 2.29 & 5.27 \\
Perceptions of tablet & 2.51 & 2.82 & .12 \\
Comfort with technology & 3.25 & 4.83 & 37.3 \\
Frequency of use tablet & 2.37 & 3.15 & .085 \\
Learning transferability & 1.90 & 2.02 & .56 \\
\hline
\end{tabular}

\section{Conclusions}

This study was undertaken to assess an iPad iLearn Program in a small School of Business after students had been provided with an on-loan tablet that would become their property after a pre-determined period of enrollment. The 26-question survey responses were used to identify which constructs would serve as predictors to learning transferability following an exploratory and confirmatory factor analysis. Comfort with technology, comfort with iPad, perceptions of iPad, and frequency of use were all significant predictors of learning transferability with comfort with iPad being by far the best predictor. The adjusted $\mathrm{R}^{2}$ explained $72 \%$ of the variance in the model.

Moreover, this study purported to test whether university support of the program and iPad ownership had any significant influence on the variables used in the construct. Independent t-test results revealed that university 
support was critical while ownership yielded mixed results. In other words, an institution or an academic unit should not commit to providing such mobile device program unless it is ready to target it to specific learning objectives and to support it with adequate technical and pedagogical resources. A unique contribution of this research is that learning transferability and perceptions of iPad did not differ between those who "owned" the device and those who "borrowed upon need". What transpires from this finding is that having access to a tablet on a permanent basis invites someone to use it more often with more ease but does not seem to contribute to value-added learning. The technology generation appears to have sufficient breadth and depth of technological tools available to sort them out according to their needs. This reinforces the point that institutions must be both selective and targeted in their technological efforts to serve this new generation.

\section{Implications}

Based on the findings in this paper, there are a few points for higher learning institutions to consider when attempting to implement tablet or mobile technology programs in their classrooms. First, a lack of proper planning can result in institutions missing out on the benefits of students' expectations regarding the use of mobile technology. It can cause institutions to lose sight of what comes after the recruitment effort. Unless there is message clarity across platforms, it is easy for schools to not fulfill the recruitment promises because their marketing efforts were ahead of what they could realistically deliver or their marketing strategy did not fit their target audience. This lack of communication can be overcome if universities carefully align their marketing strategies with their technology support services.

Second, mobile learning is not restricted to the lecture format where the professor stands at the front of the class using a one-way exchange of information. The use of tablets means that learning expands into less formal educational contexts such as peer interactions and social networks. Thus, increased frequency of the use of the tablet in all areas of life could improve learning transferability.

Third, in order to have learning transferability (i.e., comfort using the tablet for program measurement and in-class purposes, trouble shooting problems with the tablet, assisting others with their tablets and using it to complete daily tasks) students need to have positive perceptions of the tablets' worth in their courses and future workplace and comfort with technology. Given that millennials are generally quite savvy with technology in general and know how to pick and choose learning devices at their disposal, their perceptions of tablet use may be positively influenced by carefully planned and articulated programs where objectives are well spelled out and interveners well prepared. Short of that, institutions may not be maximizing their resources at the expense of students' learning and motivation.

Finally, it is important to incorporate ways to ascertain if students are getting the needed technological support. Institutional support is important as it increases comfort with technology and the tablet. However, our study found little difference in learning outcomes between those who owned a tablet and those who did not. In line with Welsh et al.'s findings (2015), institutions that want to use the tablet as a recruitment tool need to make sure they communicate the message effectively, connect the tablet to future courses and employment benefits and consider allowing students to borrow the tablet for the full term so they can take it home and use it. Students do appear to need the freedom to customize their devices to meet their individual needs, which is only possible if they have the device for the duration of their degree.

\section{Limitations and Future Research}

This study had a few limitations based on the sample size, the age of the participants and the survey timeframe. First, the data for this study was collected from a relatively small business school. Results from a larger center with greater support and financial outlays may have produced different responses. Secondly, the students who chose to participate in the survey all fell within the millennial generation who are known for being "digital natives" and having an intrinsic understanding of technology based on their lifelong exposure (Baasanjav, 2013; Kinash et al., 2012). The study had not been designed to exclude students outside of this age range but that is what did happen. "Digital immigrants" or those outside of the millennial age group who have not grown up with technology, may have struggled more or had lower levels of comfort with technology which could have changed the findings of this study.

Finally, the data was collected over a span of 8 weeks. It is reasonable to state that because of this short timeframe, some students who may have had very different experiences than the ones expressed by the participants, may not have been able to add their voices to the discussion. For example, those who were in the iPad Program during previous years or the prior term may not have been offered the opportunity to participate in the survey. 
Since this study did not explore the perceptions of professors who are responsible for implementing programs such as the iPad iLearn, future research could examine the instructors' views of the tablets and their benefits with in-class use. Future studies could explore the support needed from stakeholders to properly implement these types of endeavors and their perceptions about the value the use of these devices may have on students' future employment.

\section{References}

Alvarez, C., Alarcon, R., \& Nussbaum, M. (2011). Implementing collaborative learning activities in the classroom supported by one-to-one mobile computing: A design-based process. The Journal of Systems and Software, 84, 1961-1976. https://doi.org/10.1016/j.jss.2011.07.011

Baasanjav, U. (2013). Incorporating the experiential learning cycle into online classes. Journal of Online Learning and Teaching, 9(4), 575.

Bandura, A. (1994). Self-efficacy. Encyclopedia of Human Behavior, 4, 71-81.

Barak, M., Lipson, A., \& Lerman, S. (2006), Wireless laptops as means for promoting active learning in large lecture halls. Journal of Research on Technology in Education, 38, 245-263. https://doi.org/10.1080/15391523.2006.10782459

Barnes, N. G. (2014). Adapting our classes to reach the millennial learner. MMA Fall Educator's Conference Proceedings, 102-103.

Bennett, S. \& Maton, K. (2010). Beyond 'The Digital Natives' debate: Towards a more nuanced understanding of students' technology experiences. Journal of Computer Assisted Learning, 26(5), 321-331. https://doi.org/10.1111/j.1365-2729.2010.00360.x

Brand, J., \& Kinash, S. (2010). Pad-agogy: A quasi-experimental and ethnographic

Bullen, M., Morgan, T., \& Qayyum, A. (2011). Digital learners in higher education: Generation is not the issue. Canadian Journal of Learning Technology, 37(1), 1-24. Retrieved from http://www.cjlt.ca/index.php/cjlt

Crichton, S., Pegler, K., \& White, D. (2012). Personal devices in public settings: Lessons learned from an iPod Touch / iPad Project. The Electronic Journal of e-Learning, 10, 23-31.

Dearnley C., Haigh, J., \& Fairhall, J. (2008). Using mobile technologies for assessment and learning in practice settings: A case study. Nurse Education in Practice 8, 197-204. https://doi.org/10.1016/j.nepr.2007.07.003

Diemer, T. T., Fernandez, E., \& Streepey, J. W. (2012). Student perceptions of classroom engagement and learning using iPads. Journal of Teaching and Learning with Technology, 1, 13-25.

Dobbins, D., \& Denton, P. (2017). MyWallMate: An Investigation into the use of mobile technology in enhancing student engagement. Tech Trends, 61, 541-549. https://doi.org/10.1007/s11528-017-0188-y

Fullan, M. (2001). Leading in A Culture of Change. Jossey-Bass: San Francisco.

Gaudreau, P., Miranda, D., \& Gareau, A. (2014). Canadian university students in wireless classrooms: What do they do on their laptops and does it really matter? Computers \& Education, 70, 245-255. https://doi.org/10.1016/j.compedu.2013.08.019

Hargittai, E. (2010). Digital na(t)ives? Variation in Internet skills and uses among members of the "Net Generation." Sociological Inquiry, 80(1), 92-113. https://doi.org/10.1111/j.1475-682X.2009.00317.x

Hashim, Y. (2014). Preliminary study on teachers' use of the iPad in bachelor of education program at a private university in Malaysia. Tech Trends, 58(2), 14-19. https://doi.org/10.1007/s11528-014-0792-z

Henderson, M., Selwyn, N., Finger, G., \& Aston, R. (2015). Students' everyday engagement with digital technology in university: Exploring patterns of use and 'usefulness'. Journal of Higher Education Policy and Management, 37(3), 308-319. https://doi.org/10.1080/1360080X.2015.1034424

Jones, C., \& Czerniewicz, L. (2010). Describing or debunking? The Net generation and digital natives. Journal of Computer Assisted Learning, 26(5), 317-320. https://doi.org/10.1111/j.1365-2729.2010.00379.x

Kenny, R. F., Van Neste-Kenny, J. M., Burton, P. A., Park, C. L., \& Qayyum, A. (2012). Using self-efficacy to assess the readiness of nursing educators and students for mobile learning. The International Review of Research in Open and Distributed Learning, 13(3), 277-296. https://doi.org/10.19173/irrodl.v13i3.1221

Kinash, S., Brand, J. \& Mathew, T. (2012). Challenging mobile learning discourse through research: Student perceptions of Blackboard Mobile Learning and iPads. Australian Journal of Educational Technology, 28(4), 
639-655. https://doi.org/10.14742/ajet.832

Kukulska-Hulme A. (2013). Limelight on mobile learning - Integrating education and innovation. Harvard International Review, 34(4), 12.

Maddux, C. D., \& Johnson, D. L. (2012). External validity and research in information technology in education. Computers in the Schools, 29, 249-252. https://doi.org/10.1080/07380569.2012.703605

Magazine, M. (2012). How students rate their experiences at 62 Canadian schools: Results from the National Survey of Student Engagement. Retrieved October 3, 2012 from http://oncampus, macleans, ca/education/2012/02/08/how-students-rate-professors-at-62-canadian-schools

Mang, C. F., \& Wardley, L. J. (2012). Effective adoption of tablets in post-secondary education: Recommendations based on a trial of iPads in university classes. Journal of Information Technology Education, 11(1), 301-317. https://doi.org/10.28945/1720

Mang, C. F., \& Wardley, L. J. (2013). Student perceptions of using tablet technology in post-secondary classes. Canadian Journal of Learning \& Technology, 39(4). https://doi.org/10.21432/t22010

Margaryan, A., Littlejohn, A., \& Vojt, G. (2011). Are digital natives a myth or reality? University students' use of $\begin{array}{llll}\text { digital technologies. } \quad \text { Computers \& education, } & 56(2), & 429-440 .\end{array}$ https://doi.org/10.1016/j.compedu.2010.09.004

Morris, N. P., Ramsay, L., \& Chauhan, V. (2012). Can a tablet device alter undergraduate science students' study behavior and use of technology? Advances in Physiology Education, 36(2), 97-107. https://doi.org/10.1152/advan.00104.2011

Murphy, T., \& Williams, C. (2011, April). The iPad as a class presentation platform. In Proceedings of the 2011 ASEE Southeastern Section Conference, ASEE, Charleston, SC.

pilot test of the iPad in a blended mobile learning environment. 27th Annual Conference of the Australian Society for Computers in Learning in Tertiary Education (ASCILITE), 147-151.

Rossing, J.P., Miller, W.M., Cecil, A.K., \& Stamper, S.E. (2012). iLearning: The future of higher education? Student perceptions on learning with mobile tablets. Journal of the Scholarship of Teaching and Learning, 12(2), 1-26.

Saorin, J. L., Torre, J. D. L., Martin, N., \& Carbonell, C. (2013). Education working group management using digital tablets. Procedia-Social and Behavioral Sciences, 93, 1569-1573. https://doi.org/10.1016/j.sbspro.2013.10.083

Sloan, R. H. (2013). Using an eTextbook and iPad: Results of a pilot program. Journal of Educational Technology Systems, 41, 87-104. https://doi.org/10.2190/et.41.1.g

Sullivan, R. M. (2013). The tablet inscribed: Inclusive writing instruction with the iPad. College Teaching, 61, 1-2. https://doi.org/10.1080/87567555.2012.700339

Tanaka, P. R., Hawrylyshyn, K. A., \& Macario, A. (2012). Use of tablet (iPad) as a tool for teaching anesthesiology in an orthopedic rotation. Revista Braileira de Anestesiologia, 62(2), 214-222. https://doi.org/10.1016/s0034-7094(12)70119-8

Vu, P., McIntyre J., \& Cepero, J: (2014). Teachers' use of the iPad in classrooms and their attitudes toward using it. Journal of Global Literacies, Technologies and Emerging Pedagogies, 2(2), 58-76.

Wallace, P., \& Clariana, R. B. (2005). Perception versus reality-determining business students' computer literacy skills and need for instruction in information concepts and technology. Journal of Information Technology Education, 4, 141-151. https://doi.org/10.28945/269

Wardley, L. J., \& Mang, C. F. (2015). Student observations: Introducing iPads into university classrooms. Education and Information Technologies, 1-18. https://doi.org/10.1007/s10639-015-9414-4

Welsh, K. E., Mauchline, A. L., Powell, V., France, D., Park, J. R., \& Whalley, W. B. (2015). Student perceptions of iPads as mobile learning devices for fieldwork. Journal of Geography in Higher Education, 39(3), 450-469. https://doi.org/10.1080/03098265.2015.1066315

Wong, W. (2012). Tools of the trade: How mobile learning devices are changing the face of higher education. Community College Journal, 54-60.

Wu, C., Kuo, Y., \& Wu, S. (2013). Investigating the antecedents of university students' behavioral intention to use iPad for learning. International Journal of e-Education, e-Management and e-Learning, 3, 468-471. 
https://doi.org/10.7763/ijeeee.2013.v3.280

\section{Copyrights}

Copyright for this article is retained by the author(s), with first publication rights granted to the journal.

This is an open-access article distributed under the terms and conditions of the Creative Commons Attribution license (http://creativecommons.org/licenses/by/4.0/). 